\title{
One Hundred Percent
}

National Cancer Institute

\section{Source}

National Cancer Institute. One Hundred Percent. NCI Thesaurus. Code C158695.

All, one hundred percent. 